\title{
Attention Deficit Hyperactivity Disorder in A Rural Area of Sohag Governorate
}

\author{
Sabra M. Ahmed
}

Public Health and Community Medicine Department, Assiut university, Egypt.

Received: January, 2016 Accepted: March, 2016

\begin{abstract}
Background: Attention deficit hyperactivity disorder (ADHD) is a rising public health problem affecting child quality of life. Objectives: To estimate the prevalence and identify socio-demographic risk factors of attention deficit hyperactivity disorder (ADHD) among primary school children in a rural area of Sohag governorate. Methods: A crosssectional community based study design was carried out in two villages of Sohag governorate using structured interview questionnaire. To identify children with probable ADHD a validated questionnaire based on Diagnostic and Statistical Manual of Mental disorders, $4^{\text {th }}$ Edition (DSM IV) was used. It includes a parent's and a teacher's copy. Results: This study included 854 primary school students in two villages of Sohag governorate. The prevalence of probable ADHD was 9.6\%. The prevalence of ADHD was significantly associated with low socioeconomic level, higher birth order, male gender, smoker father, consanguineous parents, family history of ADHD, low birth weight, artificially fed children and pupils living with single parent. Conclusion and recommendations: ADHD is prevalent among primary school pupils in rural areas of Sohag governorate. Efforts are required to control associated risk factors of ADHD and reduce its prevalence.
\end{abstract}

Key Words: ADHD, Prevalence, Risk factors, Rural Sohag

Corresponding author: Sabra M. Ahmed Email: sabraa16@gmail.com

\section{Introduction}

Attention deficit hyperactivity disorder (ADHD) is defined as an active and impulsive behaviors and persistent lack of attention which are more than expected as it is usually seen in children of the same age. ${ }^{1}$ ADHD is considered the most common neuro-developmental disorder of young children that constitute a public health problem. ${ }^{2}$ ADHD is divided into hyperactive/impulsive, inattentive and combined types. Its diagnosis is based on criteria specified by the Diagnostic and Statistical Manual of Mental Disorders Fourth Edition (DSM"IV). ${ }^{3}$ A child showing 6 signs or more of the nine criteria of inattention or 6 signs or more of the nine criteria of hyperactivity-impulsivity in at least two occasions (school, home or other environments) is known to be suspected to have ADHD. ${ }^{4}$

ADHD has adverse effects on educational, cognitive, emotional, behavioral and social functions. Affected children are at risk of bad academic performance, academic failure, grade repetition, school withdrawal, bad friendships, family relationships and depression, anxiety, aggression, drug abuse at an early age, law-breaking and exclusion from peers. ${ }^{4,5}$

Children with ADHD do not obey instructions of their parents, impulsively acting, irritable and unstable emotionally. They need more attention by their 
teachers at school and they are unable to perform their homework at home. ${ }^{1}$

Moreover, it was found that symptoms of ADHD continue during adulthood for 30$70 \%$ of children with this disorder. ${ }^{6}$ Many studies found genetic, environmental factors and psychological traits and disorders played a role in the etiology of ADHD. ${ }^{7}$

The prevalence rate of ADHD among children varies widely all over the world ranging from $1 \%$ to $20 \%{ }^{8}$ The worldwide prevalence rate of ADHD was 5.3\%. ${ }^{9}$ In Arab countries the reported rate was between $1.3 \%$ to $34.5 \%$ and in Egypt it was between $6 \%$ to $19.7 \%$ for children and youth. ${ }^{10}$

There is lack of studies about the prevalence and risk factors of ADHD among primary school children in rural areas of Sohag governorate. Therefore, this study was conducted to address this issue.

The general objective was to promote proper health status of children in rural areas of Sohag governorate.

Specific objectives were to estimate the prevalence of ADHD among primary school children in a rural area of Sohag governorate and to identify the familial and socio-demographic risk factors of ADHD among primary school children in a rural area of Sohag governorate.

\section{Methods:}

Study design: A cross-sectional community-based study was carried out.

Sample size: Sample size was calculated using EPI INFO version 3.5.1 (2008). Sample size calculation was based on prevalence of ADHD of $6.9 \%(\mathrm{P}=$ 0.069). ${ }^{11}$ With a power of $80 \%$ and confidence level of $95 \%$ and a design effect of 2, the sample needed for the study was 548 students. The sample was increased to 854 .

Study site: The study was conducted in Naza Al-Baharia village (Juhina District) and Banja village (Tahta district). Both villages are located in the western and northern part of Sohag governorate. They had an estimated population of 36,500 people. Primary schools in both villages contains 4100 pupils in the academic year 2016/2017. The target population of this study was primary school children from $1^{\text {st }}$ to $6^{\text {th }}$ grade in these villages.

Instrument: Data collection was performed by using structured interview questionnaires. Two types questionnaires were used for data collection, household and ADHD questionnaires: (1) The household questionnaire includes the socio-demographic characteristics of the pupils (age, gender, family residence, education and occupation of the parents .......etc). Households were classified into high, middle and low socioeconomic levels by using El-Gilany, et al. 2012 score. $^{12}$ This score has 7 domains with a total score of 84 . Higher score indicates higher socio-economic level. Households were classified into three levels relative to each other with the higher one third [218 (33.3\%) households] constituted the high socioeconomic level and the middle and lower thirds constituted the middle and lower socio-economic levels respectively. (2) The second questionnaire was a scale to identify children with probable ADHD. This scale was developed by El-Noby, 2005 . $^{13}$ It was based on DSM IV for ADHD, and validated (Cronbach's alpha $=0.7)$ in Egypt. This scale was used by a previous study conducted in Qalyoubia governorate in Egypt. ${ }^{14}$ This scale has a teacher copy and a parent copy. Each of them contains 24 items. Responses to questions were doing the behavior rarely coded as 1 , or doing the behavior occasionally coded as 2 or doing the behavior always coded as 3 . The maximum score for either parent and teacher copy of ADHD questionnaire is 72. In order to decrease the number of false positive cases, this study considered the child probably having ADHD when he/she has a score of 48 or more in both parent and teacher's copy of ADHD 
questionnaires (a total score of $\geq 96$ for probable ADHD child). Scholastic achievement of the pupils was classified into high, middle and low according to evaluation of pupil's teacher.

The tool used by this study is a screening one and not diagnostic, therefore children found positive by this study are considered as probably having ADHD.

Procedures: Permission to conduct this study was obtained from the directorate of education in Sohag governorate. List of all houses of the villages was obtained from the Rural Health Units. A total of 854 houses were visited. All eligible children (6-12 years) in the selected houses were included. Systematic random sampling technique was used. The first house was selected randomly, and then every third house of both villages was included in this study.

Data collection was performed at home at first. All households containing eligible children ( $6-12$ years) in the selected houses were included in the study. Collection of socio-demographic data of the household was performed by interviewing either parent (mostly mother) at home. Then a parent's copy of ADHD questionnaire was filled for each eligible child. Three trained female data collectors (recent graduate of faculty of nursing) collected the required household data under strict supervision of the researcher.

All children who were subjected to data collection at home were subjected to a teacher's copy of ADHD questionnaire at school to be filled by the school teacher of the child.

Data collection was between start of September to the end of November, 2017.

Exclusion criteria: Children with known neurological disease (by asking parents and teachers) and children below $1^{\text {st }}$ grade and above $6^{\text {th }}$ grade primary school pupils.

Statistical analysis: Data entry, cleaning and analysis was done by using SPSS program, version 16. Frequencies were reported as percentages; comparisons between frequency-based data were performed using $\chi^{2}$-test. Continuous variables were compared using twotailed independent-sample t-tests. For all comparisons, the statistical level of significance was set at $\mathrm{P}<0.05$ Multivariate logistic regression analysis was performed for significant variables.

Ethical considerations: The study protocol was approved by the ethical review committee of Assiut faculty of medicine. The purpose of the study was explained to the school authorities, students and their parents. A written permission to conduct this was obtained from the directorate of education. The headmaster, all school teachers and administrators were invited to participate in this study. Also, a verbal consent was obtained from the students' parents and teachers before filling the questionnaire. They had the right to withdraw from the study at any time without any punishment. Parents of all children with probable ADHD were contacted by the researcher and advised to be furtherly evaluated by a psychiatric specialist for final and conclusive diagnosis.

\section{Results}

Table (1) shows socio-demographic characteristics of studied pupils. About one half $(51.5 \%)$ were males. The mean age was 9.1 years. Regarding education of parents, $29.6 \%$ and $38.1 \%$ of fathers and mothers were illiterate. Employed fathers and mother constituted $28.5 \%$ and $26.5 \%$ respectively. About two thirds $(63.9 \%)$ of families were nuclear. Prevalence of probable ADHD among studied children was $9.6 \%$.

Table (2) shows prevalence of probable ADHD by sociodemographic characteristics of studied pupils. Male had higher prevalence (14.5\%) of ADHD $(\mathrm{P}=<0.001)$. The prevalence of probable ADHD is higher (12.1\%) among children with illiterate or read and write fathers 
Table (1): $\quad$ Socio-demographic characteristics of primary school pupils under study in rural areas of Sohag Governorate, 2017.

\begin{tabular}{|c|c|}
\hline Characteristics & $\mathbf{N}(\%)$ \\
\hline $\begin{array}{l}\text { Gender: } \\
-\quad \text { Males } \\
-\quad \text { Females }\end{array}$ & $\begin{array}{l}440(51.5) \\
414(48.5)\end{array}$ \\
\hline $\begin{array}{l}\text { Age: } \\
-\quad 6- \\
-\quad 9- \\
-\quad 12-14 \\
\text { Mean } \pm \text { SD }\end{array}$ & $\begin{array}{r}322(37.7) \\
327(38.3) \\
205(24.0) \\
9.1 \pm 3.2 \\
\end{array}$ \\
\hline $\begin{array}{ll}\text { Father's education: } \\
-\quad \text { Illiterate } \\
-\quad \text { Read and write } \\
-\quad \text { Primary and preparatory } \\
-\quad \text { Secondary and higher } \\
\end{array}$ & $\begin{array}{l}253(29.6) \\
176(20.6) \\
215(25.2) \\
210(24.6)\end{array}$ \\
\hline \begin{tabular}{ll}
\multicolumn{2}{l}{ Mother's education: } \\
- & Illiterate \\
- & Read and write \\
- & Primary and preparatory \\
- & Secondary and higher
\end{tabular} & $\begin{array}{l}325(38.1) \\
214(25.0) \\
188(22.0) \\
127(14.9)\end{array}$ \\
\hline \begin{tabular}{ll}
\multicolumn{2}{l}{ Father's occupation: } \\
- & Farmer \\
- & Employee \\
- & Unskilled worker \\
- & Skilled worker \\
\end{tabular} & $\begin{array}{r}312(36.5) \\
244(28.5) \\
206(24.1) \\
92(10.8) \\
\end{array}$ \\
\hline $\begin{array}{l}\text { Mother's occupation: } \\
-\quad \text { House wife } \\
-\quad \text { Employee }\end{array}$ & $\begin{array}{l}627(73.4) \\
227(26.7)\end{array}$ \\
\hline \begin{tabular}{ll}
\multicolumn{2}{l}{ Family type: } \\
$-\quad$ Nuclear \\
$-\quad$ Extended
\end{tabular} & $\begin{array}{l}546(63.9) \\
308(36.1)\end{array}$ \\
\hline \begin{tabular}{ll}
\multicolumn{2}{l}{ Socio-economic level: } \\
$-\quad$ High \\
$-\quad$ Middle \\
$-\quad$ Low \\
\end{tabular} & $\begin{array}{l}285(33.4) \\
285(33.4) \\
284(33.3)\end{array}$ \\
\hline $\begin{array}{l}\text { Presence of probable ADHD: } \\
-\quad \text { No } \\
-\quad \text { Yes }\end{array}$ & $\begin{array}{r}772(90.4) \\
82(9.6) \\
\end{array}$ \\
\hline Total & 854 \\
\hline
\end{tabular}

$(\mathrm{P}=0.012)$. Children with employed mothers, nuclear families, lower birth orders had lower prevalence of probable $\operatorname{ADHD}(6.4 \%, 8.1 \%$ and $6.1 \%)(\mathrm{P}=0.03$, 0.02 and <0.001) respectively. Pupils with high socioeconomic level had lower prevalence of probable ADHD than those with middle and low socioeconomic level (5.6\%, 8.4\% and $14.8 \%$ respectively) (P $<0.001)$.
Table (3) shows that pupils who live with only one parent, consanguineous parents and smoker fathers had higher prevalence of probable ADHD $(20 \%$, $12.7 \%$ and $11 \%)(\mathrm{P}=0.034,0.007$ and $<0.001)$ respectively. Children with family history of ADHD, bad parent relationship and bad child-parent relationship and those with higher maternal age and low scholastic achievement had higher prevalence of ADHD $(13.4 \%, 12,3 \%, 13.7 \% 12.1 \%$ and $17.5 \%)(\mathrm{P}=0.01,0.022,<0.001$, 0.014 and 0.007$)$ respectively.

Table (4) shows that pre-term children and those with low birth weight had higher prevalence of probable ADHD $(13.6 \%$ and $14.6 \%) \quad(\mathrm{P}=0.012$ and 0.002) respectively. Children with history of birth trauma, toxemia of pregnancy, artificial feeding had higher prevalence of probable ADHD (14.6\%, $15.8 \%$, and $12.4 \%)(\mathrm{P}=<0.001,0.012$, and 0.029$)$ respectively.

Table (5) shows logistic regression analysis for variables related to ADHD. Prevalence of ADHD was significantly associated with low socioeconomic level, higher birth order, male gender, smoker father, consanguineous parents, family history of ADHD, low birth weight, artificially fed children and pupils living with single parent.

\section{Discussion}

This population based studies included 854 primary school students distributed in two villages in Sohag governorate. The socio-demographic characteristics of study population reflects the characteristics of primary school children in rural areas of Sohag governorate.

The prevalence rate of ADHD among the studied students in this study was $9.6 \%$. The reported rate in this study is higher than that reported by studies conducted in Menofia governorate, Egypt $(2014)^{11}$ (6.9\% among 1,362 primary school students), El-Minia city, Egypt (2010) ${ }^{15}$ (6.5\% among 4,223 preschool and school 
Table (2): Distribution of ADHD among studied school pupils by socio-demographic characteristics in rural areas of Sohag governorate, 2017.

\begin{tabular}{|c|c|c|c|}
\hline \multirow{2}{*}{ Characteristics } & \multicolumn{2}{|c|}{ Presence of probable ADHD } & \multirow{2}{*}{$\mathrm{P}$} \\
\hline & Yes (82) & No (772) & \\
\hline $\begin{array}{l}\text { Age: } \\
-\quad 6- \\
-\quad 9- \\
-\quad 12-14\end{array}$ & $\begin{array}{r}33(10.2) \\
32(9.8) \\
17(8.3) \\
\end{array}$ & $\begin{array}{l}289(89.8) \\
295(90.2) \\
188(91.7)\end{array}$ & 0.751 \\
\hline \begin{tabular}{ll}
\multicolumn{2}{l}{ Gender: } \\
$-\quad$ Males \\
$-\quad$ Females
\end{tabular} & $\begin{array}{r}68(14.5) \\
14(3.6)\end{array}$ & $\begin{array}{l}402(85.5) \\
370(96.3)\end{array}$ & $<0.001$ \\
\hline $\begin{array}{ll}\text { Father's education: } \\
-\quad \text { Illiterate / read \& write } \\
-\quad \text { Primary \& prep. } \\
-\quad \text { 2ry and higher } \\
\end{array}$ & $\begin{array}{r}52(12.1) \\
20(9.3) \\
10(4.8) \\
\end{array}$ & $\begin{array}{l}377(87.9) \\
195(90.7) \\
200(95.2)\end{array}$ & 0.012 \\
\hline $\begin{array}{ll}\text { Mother's education: } \\
-\quad \text { Illiterate / read \& write } \\
-\quad \text { Primary \& prep. } \\
-\quad \text { 2ry and higher }\end{array}$ & $\begin{array}{r}55(10.2) \\
18(9.6) \\
9(7.1)\end{array}$ & $\begin{array}{l}484(89.8) \\
170(90.4) \\
118(92.9)\end{array}$ & 0.562 \\
\hline \begin{tabular}{ll}
\multicolumn{2}{l}{ Father's occupation: } \\
- & Farmer \\
- & Employee \\
- & Unskilled worker \\
- & Skilled worker \\
\end{tabular} & $\begin{array}{r}25(8.0) \\
15(7.5) \\
21(8.5) \\
11(12.0) \\
\end{array}$ & \begin{tabular}{r|}
$287(92.0)$ \\
$189(92.5)$ \\
$225(91.5)$ \\
$81(88.0)$ \\
\end{tabular} & 0.601 \\
\hline $\begin{array}{l}\text { Mother's occupation: } \\
-\quad \text { House wife } \\
-\quad \text { Employee }\end{array}$ & $\begin{array}{r}65(11.1) \\
17(6.4) \\
\end{array}$ & $\begin{array}{l}522(88.9) \\
250(93.6)\end{array}$ & 0.030 \\
\hline $\begin{array}{ll}\text { Family type: } \\
-\quad \text { Nuclear } \\
-\quad \text { Extended } \\
\end{array}$ & $\begin{array}{r}42(8.4) \\
40(11.6) \\
\end{array}$ & $\begin{array}{l}496(91.6) \\
276(88.4)\end{array}$ & 0.020 \\
\hline $\begin{array}{l}\text { Birth order: } \\
-\quad 1^{\text {st }} \\
-\quad 2^{\text {nd }}-4^{\text {th }} \\
-\quad \geq 5^{\text {th }}\end{array}$ & $\begin{array}{r}17(6.1) \\
26(7.1) \\
39(18.6)\end{array}$ & $\begin{array}{l}260(93.9) \\
341(92.9) \\
171(81.4)\end{array}$ & $<0.001$ \\
\hline Family size $($ Mean \pm SD): & $8.4 \pm 4.1$ & $7.2 \pm 2.9$ & $<0.001$ \\
\hline \begin{tabular}{ll}
\multicolumn{2}{l}{ Socio-economic level* } \\
- & High \\
- & Middle \\
- & Low \\
\end{tabular} & $\begin{array}{r}16(5.6) \\
24(8.4) \\
42(14.8) \\
\end{array}$ & $\begin{array}{l}269(33.4) \\
261(33.4) \\
242(33.3) \\
\end{array}$ & $<0.001$ \\
\hline Total & $82(9.6)$ & $772(90.4)$ & \\
\hline
\end{tabular}

*Using El-Gilany et al. score (2012).

children aged $4-12$ years), Assiut city, Egypt $(2005)^{16}$ (6\% among 1513 third grade primary school students). Also, the reported rate in this study is lower than that reported by studies conducted in $\mathrm{Al}$ Qalyobia governorate, Egypt $(2017)^{14}$ $(21.8 \%$ and $16.2 \%$ among 921 primary school children according to teacher and parent scale respectively) and Alexandria city, Egypt $(1994)^{17}(19.5 \%$ among 501 first and second years of primary schools). Also, it is lower than that reported among 600 children aged 5-12 years attending pediatric clinic of Menofia university hospital (Egypt $)^{18}$ which was $19.7 \%$.

In Arab countries the reported rate was between $1.3 \%$ to $34.5 \%^{10}$, The

worldwide prevalence rate of ADHD was $5.3 \%{ }^{9}$

This shows that prevalence of ADHD shows high variability even within the same country. The difference in the prevalence rate reported by this study 
and other studies in Egypt may be due to differences in age of the children under study and differences in the sample size and tool and methodology of the study

Table (3): Distribution of studied primary school pupils by familial characteristics in rural areas of Sohag Governorate, 2017.

\begin{tabular}{|c|c|c|c|}
\hline \multirow{2}{*}{ Characteristics } & \multicolumn{2}{|c|}{ Presence of probable ADHD } & \multirow{2}{*}{$P$ - value } \\
\hline & Yes (82) & No (772) & \\
\hline $\begin{array}{ll}\text { Student live with: } \\
-\quad \text { Both parents } \\
\text { - } & \text { Single parent }\end{array}$ & $\begin{array}{r}61(8.6) \\
21(20.0)\end{array}$ & $\begin{array}{l}646(91.4) \\
126(80.0)\end{array}$ & 0.034 \\
\hline $\begin{array}{l}\text { Parents' consanguinity: } \\
-\quad \text { Yes } \\
-\quad \text { No } \\
\end{array}$ & $\begin{array}{r}47(12.7) \\
35(7.2) \\
\end{array}$ & $\begin{array}{l}323(87.3) \\
449(92.8) \\
\end{array}$ & 0.007 \\
\hline $\begin{array}{l}\text { Smoker fathers: } \\
-\quad \text { Yes } \\
-\quad \text { No }\end{array}$ & $\begin{array}{r}55(11.0) \\
27(6.0)\end{array}$ & $\begin{array}{l}347(89.0) \\
425(94.0)\end{array}$ & $<0.001$ \\
\hline $\begin{array}{ll} & \text { Parent's response to child mistake } \\
\text { - } & \text { Explain quietly } \\
- & \text { Emotional violence } \\
- & \text { Physical violence }\end{array}$ & $\begin{array}{r}22(7.5) \\
38(10.0) \\
22(12.0)\end{array}$ & $\begin{array}{l}270(92.5) \\
341(90.0) \\
161(88.0)\end{array}$ & 0.252 \\
\hline $\begin{array}{l}\text { Family history of ADHD } \\
-\quad \text { Yes } \\
-\quad \text { No }\end{array}$ & $\begin{array}{r}36(13.4) \\
46(7.3)\end{array}$ & $\begin{array}{l}232(86.6) \\
540(92.7)\end{array}$ & 0.010 \\
\hline $\begin{array}{l}\text { Family history of other mental diseases } \\
-\quad \text { Yes } \\
-\quad \text { No }\end{array}$ & $\begin{array}{l}36(9.8) \\
46(9.5)\end{array}$ & $\begin{array}{l}332(90.2) \\
440(90.5)\end{array}$ & 0.076 \\
\hline $\begin{array}{l}\text { Watching TV: } \\
-\quad<2 \text { hours / day } \\
-\quad \geq 2 \text { hours / day }\end{array}$ & $\begin{array}{r}36(12.0) \\
46(8.3) \\
\end{array}$ & $\begin{array}{l}265(88.0) \\
507(91.7)\end{array}$ & 0.084 \\
\hline $\begin{array}{l}\text { Parents' relationship: } \\
-\quad \text { Good } \\
-\quad \text { Bad }\end{array}$ & $\begin{array}{r}37(7.6) \\
45(12.3)\end{array}$ & $\begin{array}{l}450(92.4) \\
322(87.7)\end{array}$ & 0.022 \\
\hline $\begin{array}{l}\text { Child-parent relationship: } \\
-\quad \text { Good } \\
-\quad \mathrm{Bad} \\
\end{array}$ & $\begin{array}{r}31(6.4) \\
51(13.7) \\
\end{array}$ & $\begin{array}{l}451(93.6) \\
321(86.3) \\
\end{array}$ & $<0.001$ \\
\hline $\begin{array}{l}\text { Maternal age at birth: } \\
-\quad>35 \text { years } \\
-\quad \leq 35 \text { years }\end{array}$ & $\begin{array}{r}51(12.1) \\
31(7.2)\end{array}$ & $\begin{array}{l}370(87.9) \\
402(92.8)\end{array}$ & 0.014 \\
\hline \begin{tabular}{ll}
\multicolumn{2}{l}{ Scholastic achievement } \\
$-\quad$ High \\
$-\quad$ Middle \\
$-\quad$ Low \\
\end{tabular} & $\begin{array}{r}26(8.2) \\
35(8.4) \\
21(17.5) \\
\end{array}$ & $\begin{array}{r}291(91.5) \\
382(91.8) \\
99(82.5)\end{array}$ & 0.007 \\
\hline Total & $82(9.6)$ & $772(90.4)$ & \\
\hline $\begin{array}{l}\text { addition to differences in the soci } \\
\text { emographic and cultural characteristi } \\
\text { f the study population. } \\
\text { lhraiwil, et al. } 2015^{19} \text { in their revie } \\
\text { bout ADHD in Arab countries fou } \\
\text { lat studies which used Conner rati } \\
\text { cale for parents and teachers show } \\
\text { revalence range of ADHD betwe } \\
4 \% \text { and } 9.9 \% \text {, on the other hand studi }\end{array}$ & $\begin{array}{l}\text { which us } \\
\text { or self-re } \\
\text { showed } \\
14.75 \% \text { t } \\
\text { combined } \\
\text { (consenst } \\
\text { which yi } \\
\text { reported } \\
\text { separatel }\end{array}$ & $\begin{array}{l}\text { linical intervie } \\
\text { ted questionn } \\
\text { valence ran } \\
6 \% \text {. This stuc } \\
\text { rent and teach } \\
\text { for detection } \\
\text { lower prevale } \\
y \text { teachers }\end{array}$ & $\begin{array}{l}\text { vs (in Egypt) } \\
\text { ire (in Iraq) } \\
\text { e between } \\
\text { depends on } \\
\text { agreement } \\
\text { of ADHD } \\
\text { ce than that } \\
\text { or parents }\end{array}$ \\
\hline
\end{tabular}


Table (4): Distribution of studied primary school pupils by some obstetric factors in rural areas of Sohag Governorate, 2017.

\begin{tabular}{|c|c|c|c|}
\hline \multirow{2}{*}{ Characteristics } & \multicolumn{2}{|c|}{ Presence of probable ADHD } & \multirow{2}{*}{$P$ - value } \\
\hline & Yes (82) & No (772) & \\
\hline \begin{tabular}{ll}
\multicolumn{2}{l}{ Delivery mode: } \\
$-\quad$ Vaginal \\
$-\quad$ Caesarian section
\end{tabular} & $\begin{array}{r}49(8.9) \\
33(10.9)\end{array}$ & $\begin{array}{l}501(91.1) \\
271(88.1)\end{array}$ & 0.355 \\
\hline $\begin{array}{l}\text { Pregnancy duration: } \\
-\quad \text { Full term } \\
-\quad \text { Pre-term }\end{array}$ & $\begin{array}{r}49(8.0) \\
33(13.6)\end{array}$ & $\begin{array}{l}562(92.0) \\
210(86.4)\end{array}$ & 0.012 \\
\hline $\begin{array}{l}\text { Birth weight: } \\
-\quad \text { Normal } \\
-\quad \text { Low birth weight }\end{array}$ & $\begin{array}{r}48(7.7) \\
34(14.6) \\
\end{array}$ & $\begin{array}{l}573(92.3) \\
199(85.4) \\
\end{array}$ & 0.002 \\
\hline \begin{tabular}{ll}
\multicolumn{2}{l}{ History of birth trauma } \\
$-\quad$ No \\
$-\quad$ Yes \\
\end{tabular} & $\begin{array}{r}51(7.9) \\
31(14.6) \\
\end{array}$ & $\begin{array}{l}591(92.1) \\
181(85.4)\end{array}$ & $<0.001$ \\
\hline \begin{tabular}{l}
\multicolumn{1}{l}{ Toxemia of pregnancy } \\
$-\quad$ Yes \\
$-\quad$ No \\
\end{tabular} & $\begin{array}{r}19(15.8) \\
63(8.6) \\
\end{array}$ & $\begin{array}{l}101(84.2) \\
671(91.4) \\
\end{array}$ & 0.012 \\
\hline $\begin{array}{l}\text { Feeding during infancy: } \\
-\quad \text { Breastfeeding } \\
-\quad \text { Artificial feeding }\end{array}$ & $\begin{array}{r}42(7.9) \\
40(12.4) \\
\end{array}$ & $\begin{array}{l}490(92.1) \\
282(87.6)\end{array}$ & 0.029 \\
\hline Total & $82(9.6)$ & $772(90.4)$ & \\
\hline
\end{tabular}

This study found a number of associated risk factors related to ADHD. Regarding gender, this study found significantly higher prevalence of ADHD among boys (14.5) than girls (3.6). This is consistent with results reported by studies conducted in $\mathrm{Egypt}^{11,15,16,18}, \operatorname{Iran}^{20,21}$, Iraq $^{22}$ and China. ${ }^{23}$ On the other hand, studies conducted in Qalyobia ${ }^{14}$ and Alexandria $^{17}$ (Egypt) found no significant differences between prevalence of ADHD among males and females.

The current study reveals no significant differences between prevalence of ADHD and age of the pupils. Similar result was reported by a study conducted in Menofia governorate, Egypt. ${ }^{11}$ This disagreed with a study conducted in Qalyobia governorate, Egypt. ${ }^{14}$

Results of this study found that prevalence of ADHD is significantly associated with family characteristics. There is high prevalence among higher birth order $\left(\geq 4^{\text {th }}\right)$, larger family size and low socio-economic level. Increasing birth order may be associated with larger family size and older maternal age at birth. This is consistent with similar studies in Egypt ${ }^{11,14,15,17,18}$ and Saudi Arabia. $^{24}$ This is inconsistent with a study conducted in Assiut city (Egypt) which found no significant association between social level and presence of ADHD. ${ }^{16}$ On the other hand, a study conducted in Iraq $^{22}$ found a significant association between ADHD and higher socio-economic level of the family.

This study found significant association between ADHD and parent's consanguinity. This is consistent with studies done in Menofia and Qalyobia governorates (Egypt). ${ }^{11,14}$

This study shows statistically higher prevalence of ADHD among children with single parents. This finding was similar to other studies in Egypt ${ }^{11,14,18}$, and Saudi Arabia. ${ }^{24}$ Separation of parents by divorce or travel or death is associated with negative impact on children's behavior, more violence and criticism. ${ }^{24}$ 
Table (5): Odds ratio for correlates of ADHD among primary school children in rural Sohag governorate, 2017.

\begin{tabular}{|l|r|r|}
\hline \multicolumn{1}{|c|}{ Variables } & Odds ratio (95\% CI) & P value \\
\hline Socio-economic level (low) & $8.71(3.14-22.54)$ & $<0.001$ \\
\hline Birth order $\left(\geq 5^{\text {th }}\right)$ & $7.52(2.67-21.34)$ & $<0.001$ \\
\hline Gender (male) & $6.83(2.59-18.01)$ & $<0.001$ \\
\hline Smoker father (yes) & $4.57(1.74-11.69)$ & $<0.001$ \\
\hline Parent consanguinity (yes) & $4.55(3.54-7.93)$ & 0.001 \\
\hline Family history of ADHD (yes) & $4.34(3.35-7.66)$ & 0.007 \\
\hline Birth weight (low) & $3.62(1.93-5.94)$ & 0.010 \\
\hline Feeding during infancy (artificial) & $1.52(1.25-1.96)$ & 0.002 \\
\hline Pupil live with single parent & $1.42(1.25-1.98)$ & 0.029 \\
\hline
\end{tabular}

Similar to previous studies ${ }^{14,15,16,18,24}$, this study shows that artificial feeding is associated with higher prevalence of ADHD. This may be due to deprivation of child from maternal contact and warm feelings during breastfeeding. This is in addition to the advantages of breastfeeding over the artificial feeding. According to the result of current study, preterm birth and low birth weight were significantly associated with higher prevalence of ADHD. Similar results were reported by studies in Egypt ${ }^{11,15,18}$ and Saudi Arabia. ${ }^{24}$

The prevalence of ADHD was significantly associated with family history of ADHD and other mental health problems. This is in line with other studies conducted in Egypt. ${ }^{11,16,18}$.

In concordance with previous studies $^{11,14,25}$, current study found that father smoking was significantly associated with ADHD. Paternal smoking exposes the mother and newborn child to health hazards of passive smoking. Smoking during pregnancy is well known to result in low birth weight babies. Also, exposure to carbon monoxide of smoking during pregnancy could account for development of ADHD. ${ }^{25}$ The present study shows lower educational achievement among pupils with ADHD than normal pupils. In line with this result, studies conducted in Alexandria, El Minia governorates (Egypt $)^{15,17}$ and Saudi Arabia. ${ }^{24}$ This can be explained by higher activity and lack of concentration by children with ADHD.

\section{Conclusion and Recommendations:}

ADHD is present among $9.6 \%$ of studied primary school children in rural areas of Sohag governorate. This rate is comparable with studies conducted in Egypt. A number of risk factors was significantly associated with ADHD. Efforts are required to control the modifiable associated risk factors of ADHD to decrease its prevalence. Early detection of ADHD has an important role in the prevention of negative impact on the child, his family and the community.

\section{References:}

1. Karbasi A S, Golestan M, Fallah R, Sadr Bafghi M. (2008): Prevalence of attention deficit hyperactivity disorder in 6 year olds of Yazd city. Journal of Shahid Sadoughi University of Medical Sciences and Health Services 2008; 15: 29- 34.

2. Dickstein, L.J., Roba, M.B. and Oldham, J.M. (1997): Review of psychiatry. American Psychiatric Press. Washington, DC. London, England.

3. American Psychiatric Association (APP) (1994): Diagnostic and Statistical Manual of Mental Disorders. 4th edition Washington, D.C; 1994. (1)

4. Moayedi F, Moayedi A, Goli G, Hemedi Y. (2013): Prevalence of attention deficit hyperactivity disorder in Bandarabbas primary school students in 
2010. Journal of Hormozgan University of Medical Sciences; 3(17): 12-18.

5. Shahim S, Mehrangiz L, Yousefi F. (2007): Prevalence of attention deficit hyperactivity disorder in a group of elementary school children. Iran $\mathbf{J}$ Pediatr; 17(suppl 2): 211-16.

6. Faraone SV, Biederman J, Spencer T, Wilens T, Seidman LJ, Mick E (2000): Attention-deficit/hyperactivity disorder in adults: an overview. Biol psychiatry; 48:9-20.

7. Plomin R, DeFries JC, McClearn GE, McGuffin P. (2001): Behavioral genetics. 4th ed. New York (NY): Worth Publishers; 2001.

8. Polanczyk, G., de Lima, M. S., Horta, B. L., Biederman, J., \& Rohde, L. A. (2007): The Worldwide Prevalence of ADHD: A Systematic Review and Meta regression Analysis. The American Journal of Psychiatry, 164, 942-948.

9. Bener A, Al Qahtani R, Teebi AS, Bessisso M. (2008): The prevalence of attention deficit hyperactivity symptoms in school children in a highly consanguineous community. Med Princ Pract. 17:440-446.

10. Alkhateeb JM; and Alhadidi MS (2016): ADHD Research in Arab Countries: A Systematic Review of Literature, Journal of Attention Disorders; $1-15$.

11. Farahat, T., Alkot, M., Rajab, A., \& Anbar, R. (2014): Attention-deficit hyperactive disorder among primary school children in Menoufia governorate, Egypt. International Journal of Family Medicine, 2014, Article ID 257369.

12. El-Gilany A, El-Wehady A, ElWasify M. (2012): Updating and validation of the socioeconomic status scale for health research in Egypt. East Mediterr Health J; 18(9):962-968.

13. El-Noby SE. (2005): Attentiondeficit/hyperactivity disorder scale. 1st ed. Cairo: Anglo Library; 2005.

14. EL-Gendy SD, El-Bitar EA, ElAwady MA, Bayomy HFand Agwa EM (2017): Attention-Deficit/Hyperactivity
Disorder: Prevalence and risk factors in Egyptian primary school children, The Egyptian Journal of Community Medicine, 35(1): 1-16.

15. Soliman GT, Afify MF, Yehia MA, Abdel-Naem EA, Abdalkarim SM. (2010): Attention deficit hyperactivity disorder, an epidemiological study of preschool and primary school children in Minia city. El-Minia Med Bul; 21(1):171-179.

16. El-Tallawy HN, Hassan WA, ElBehary AA, Shehata GA. (2005): Prevalence of attention deficit hyperactivity disorder among elementary school children in Assiut city, Egypt. Egypt J Neurol Psychiat Neurosurg; 42(2):517-526.

17. Rashed S, Hidayet NM, Salama HM Ibrahim AG and Salem AL (1994): Epidemiologic study of attention deficit hyperactivity disorder (ADHD) in elementary schools in Alexandria governorate, Bull. Alex. Fat. Med. XXX (1): 165 - 170.

18. El-Nemr FM, Badr HS, and Salem MS, (2015): Prevalence of Attention Deficit Hyperactivity Disorder in Children, Science Journal of Public Health; 3(2): 274-280.

19. Alhraiwil NJ, Ali A, Househ MS, Al-Shehri AM, El-Metwally AA (2015): Systematic review of the epidemiology of ADHD in Arab countries. Neurosciences; 20(2): 137 - 144.

20. Arjmandi S, Akikhavandi $S$ and Sayehmiri K (2015): Prevalence of attention deficit hyperactivity disorder among primary school children according to teachers and parents' report: Systematic review and meta-analysis study, Fundamentals of Mental Health, $213-221$.

21. Alizadeh H, Armion E, Coolidge FL, Flores ZD and Sutton CE (2015): The Prevalence of ADHD among Primary School Students in an Iranian Rural Region, Psychology, 6, 263-268.

22. Shakir LN and Sulaiman KH (2016): Prevalence of Attention Deficit 
Hyperactivity among Children Attending Outpatient Clinic in Psychiatric Teaching Hospital in Erbil City, Journal of Education and Practice, 7 (23): 129 -135. 23. Huang $\mathrm{Y}$, Zheng $\mathrm{S}, \mathrm{Xu} \mathrm{C}$, lin $\mathrm{K}$, Kusheng $\mathrm{Wu}$, Zheng $\mathrm{M}$, Zhang $\mathrm{J}$ and $\mathrm{Xu}$ H (2017): Attention-defcit hyperactivity disorder in elementary school students in shantou, china: prevalence, subtypes, and influencing factors, Neuropsychiatric disease and treat., 13: 785-792.

24. Al Hamed JH, Taha AZ, Sabra AA and Bella A (2008): Attention Deficit
Hyperactivity Disorder (ADHD) among Male Primary School Children in Dammam, Saudi Arabia: Prevalence and Associated Factors, J Egypt Public Health Assoc; 83 (3 \& 4): 165 - 182.

25. Nigg J.T and Breslau N (2007): Prenatal smoking exposure, low Birth weight, and disruptive behavior disorders, Journal of the American Academy of Child and Adolescent Psychiatry, 46 (3): 362-369. 